\title{
Status Halal of Cosmestic Products: An Analysis of Alcohol Usage for Selected Skin Toner Products in Malaysia
}

Nur Bahirah Baharum, Mohd Daud Awang, Syariena Arshad, Siti Salwa Abd Gani, Amini Amir Abdullah, Hasri Mustafa and Kamarulzaman Ismail

To Link this Article: http://dx.doi.org/10.6007/IJARBSS/v11-i12/11019～DOI:10.6007/IJARBSS/v11-i12/11019

Received: 05 October 2021, Revised: 07 November 2021, Accepted: 30 November 2021

Published Online: 17 December 2021

In-Text Citation: (Baharum et al., 2021)

To Cite this Article: Baharum, N. B., Awang, M. D., Arshad, S., Gani, S. S. A., Abdullah, A. A., Mustafa, H., \& Ismail, K. (2021). Status Halal of Cosmestic Products: An Analysis of Alcohol Usage for Selected Skin Toner Products in Malaysia. International Journal of Academic Research in Business and Social Sciences, 11(12), 1072-1084.

\section{Copyright: (c) 2021 The Author(s)}

Published by Human Resource Management Academic Research Society (www.hrmars.com)

This article is published under the Creative Commons Attribution (CC BY 4.0) license. Anyone may reproduce, distribute, translate and create derivative works of this article (for both commercial and non0-commercial purposes), subject to full attribution to the original publication and authors. The full terms of this license may be seen at: http://creativecommons.org/licences/by/4.0/legalcode

Vol. 11, No. 12, 2021, Pg. $1072-1084$

Full Terms \& Conditions of access and use can be found at http://hrmars.com/index.php/pages/detail/publication-ethics 


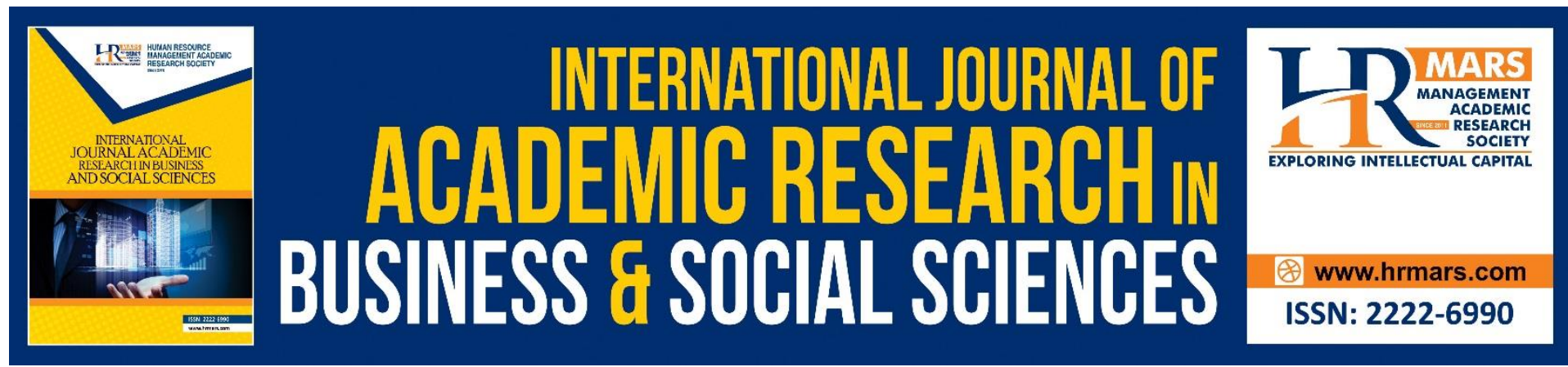

\title{
Status Halal of Cosmestic Products: An Analysis of Alcohol Usage for Selected Skin Toner Products in Malaysia
}

\author{
Nur Bahirah Baharum ${ }^{1}$, Mohd Daud Awang ${ }^{1,2}$, Syariena \\ Arshad ${ }^{1}$, Siti Salwa Abd Gani ${ }^{1,3}$, Amini Amir Abdullah², Hasri \\ Mustafa ${ }^{4}$ and Kamarulzaman Ismail ${ }^{4}$ \\ ${ }^{1}$ Halal Products Research Institute, Universiti Putra Malaysia, ${ }^{2}$ Department of Government \\ and Civilization Studies, Faculty of Human Ecology, Universiti Putra Malaysia, ${ }^{3}$ Department \\ of Agriculture Technology, Faculty of Agriculture, Universiti Putra Malaysia, ${ }^{4}$ School of \\ Business and Economics, Universiti Putra Malaysia, Selangor, Malaysia
}

\begin{abstract}
Alcohol is an organic solvent that is generally used in research and industry especially in food and beverage products. It is also widely used in cosmetic industries to produce cosmetic lines such as perfume, skin toner, and personal care products. However, the status of alcohol usage in skin toner from Syariah and scientific point of views are limited. Thus, the purpose of this study is to know the status of alcohol usage in skin toner products. This study regards the use of alcohol in cosmetic products and halal status of alcohol in branded cosmetic products in Malaysia. It also acknowledges the types of alcohol compound and the function of its safety to the consumer. The methodology of the study uses laboratory research to analyse data and obtain more regular and complete information. This study also uses a high-tech systematic tool, namely GC-MS. Gas chromatography-mass spectrometry (GC-MS) is utilised to identify alcohol substance in the cosmetic products. Results showed that ten alcohol compounds were identified in the sample facial skin toner products. These alcohols were 1,3-butanediol, 2phenoxy ethanol, 1,2-pentanediol, octanol, ethanol, phenyl ethyl alcohol, benzyl alcohol, propanol, benzene methanol, and citronellol. These alcohols are used as cleaning agents and solvents in cosmetic products and are suitable to be applied to the skin. Among these ten alcohol compounds, three compounds were found with the highest percentages which were 2-phenoxy ethanol $(92.75 \% \pm 0.72 \%)$, benzyl alcohol $(33.95 \% \pm 7.12 \%)$ and 1,2 -pentanediol $(15.29 \% \pm 6.59 \%)$. The results of this study demonstrate that the alcohol in cosmetics is produced by the scientific process and chemical reaction. The GC-MS device is considered to be the synthesis process. The results of the observations and interviews of the partresearchers with science officials state that the alcohol compounds found in this study indicates the properties of this alcohol as a cleaning agent, a solvent on the outside only and safe for use. Furthermore, this study proves that the use of alcohol in skin toner products is permissible in Islam if the alcohol is derived from plants, fruits, and grains. In other word, the status of alcohol usage in skin toner products is permissible according to Syariah.
\end{abstract}


Keywords: Alcohol, Skin Toner, Syariah, Halal, Alcohol

\section{Introduction}

Islam does not forbid the nature of any man or woman to be beautiful if it is within the permissible scope and moderate. Beauty is a subjective matter for every woman. Undoubtedly, many women in the modern era of globalisation are more concerned with the beauty of appearance than the beauty of the soul. They are willing to pursue and spend a lot of money on cosmetics to get brighter skin and beautiful looks. Cosmetics also is a symbol of beauty for a woman. It is also a reflection of personality traits and self-confidence when going through daily life. Almost women prefer to use cosmetic products to look beautiful.

Recently, there has been a wide use of alcohol in cosmetic products. In fact, alcohol is used as one of the ingredients in daily care products such as perfumes and skincare products to help other ingredients penetrate better into the skin and act as a preservative. Nevertheless, alcohol is always mistaken with the Khamr or liquor, which is in alcoholic beverage prohibited in hadith the Prophet of Muhammad (peace be upon him [PBUH]) said, 'Every intoxicant is Khamr and very intoxicant is haram (forbidden)' (Riwayat Muslim and Ad-Daruquthuny). Based on Al-Qaradhawi (2016/1960), the Khamr is the intoxicating substance of alcohol. However, there is not all alcohol is actually illegal in Islam unless it is extracted from Khamr. Alcohol is also known as ethanol or ethyl alcohol and can be found in various cosmetic products. According to Mahaiyadin and Osman (2017), alcohol is a type of chemical that has many uses. Alcohol such as methanol and ethanol are derived from wood and cereal, respectively. The alcohol used in cosmetic products is volatile, flammable, colourless, and has a distinctive aroma (Mulaina, 2014). However, the status of alcohol found in cosmetics needs to be determined profoundly and accurately by Islamic scholars and scientists.

Therefore, this article presents the analysis of alcohol in skin toner products, and the next section discusses the methodology used for this study. In addition, this article also discusses the status of alcohol in cosmetic products according to Syariah.

\section{Methodology}

This study applied data analysis of cosmetic products to identify the information of alcohol contained in the tested skin toner products. Laboratory research can help researchers gain a deeper understanding of the types of alcohol compounds. During the laboratory research, the researchers interviewed researcher Syariena Arshad in the laboratory of the Institute of Halal Products (IPPH) at Universiti Putra Malaysia, to explain alcohol compounds and their effects on the skin. In addition, this research also used a high-tech, systematic tool, namely GC-MS. Gas chromatography-mass spectrometry (GC-MS) to identify alcohol substance in the cosmetic products. All samples were studied and listed to summarize the analysis using the best method. This method can help researchers obtain information more quickly and easily. The purpose of this method is intended to obtain supplementary data. This analysis has been conducted at Halal Products Research Institute in Universiti Putra Malaysia. Secondary data from academic materials consisting of various source of journal, articles, website, and other reading materials are also referred to determine the statute of alcohol within the products according to the Syariah law.

\section{Literatures Review}

Alcohol is the common name that has always been a conversation between current and earlier scholars. The use of alcohol is not only found in certain food and beverage product, 
but also most widely used in cosmetics such as perfume, skin care products, and other. If the use of alcohol in foods and beverages are not permissible, but there are some disputes over the use of alcohol in cosmetics products. Therefore, this study will share many studies that have discussed about the halal status of using alcohol in products.

According to Hashim \& Hashim (2013), the sources of ingredients of halal cosmetic products can include halal animals (land and aquatic), plants, microorganism, alcohol, chemicals, soil, and water as long as they are not hazardous and najs. But the presence of alcohol, specifically, ethanol in cosmetics caused great concern among Muslim consumers. Furthermore, Swidi et al. (2010) explained that the Muslim consumers globally have the right to know about the ingredients of the cosmetics, personal care products, and the 'halalness' of these products to avoid using products with alcohol, pork fat, and non-halal animal ingredients.

Teng (2013) stated that halal products must not contain ingredients that are not permissible or questionable such as alcohol, toxic chemicals, fats, placenta, and gelatine from swine or animals that are not slaughtered according to the Islamic rules. Furthermore, most of the cosmetics and other personal care products are made by manufactures in non-Muslim countries and are considered suspicious in terms of their halal status. Many international brands could be using enzymes extracted from pork or alcohol as a preservative. This view generates a lot of cynicism about these brands among Muslim consumers who are seeking halal products for purchase (Briliana \& Mursito, 2017).

Kamaljeet Kaur (2014) has explained that halal cosmetic products must not contain any human part or ingredients from any forbidden animal to Muslims or slaughtered animal against Syariah law, genetically modified organism (GMO) which are decreed as najs, alcoholic drinks (Khamr), contamination from najs during preparation processing, manufacturing and storage, and must be safe for consumers. Nor, Ahmad, Yunus and Rose (n.d.) stated that it is difficult to find ethical cosmetic products that are halal and merely free from animal byproducts, harmful chemicals, or alcohol.

Azmi (2017) stated that the usage of alcohol in food, drinks, perfumes, and medicine in a special discussion of the Fatwa Committee of the National Council for Islamic Religious Affairs Malaysia on 2011 was decided as follows: Alcohol derived from the brewing process is haram (illegal) and considered as filth, but alcohol derived from non-liquor production processes is not filth but haram to drink because it is poisonous and harmful. Besides that, according to Elasrag (2016), alcohol which is used in various forms, both for the maintenance of machinery and in the products themselves, is one of the aspects in halal standard guidelines that differ among countries.

Yarkhan (2018) explained all the products with names ending in alcohol are not products to be consumed orally. They are not related to the Khamr, the common intoxicating alcoholic drink, and hence they are halal for use in skincare products only. In general, Mohezar et al. (2016) explained that this differs from the conventional product lines. The halal cosmetic brands do not contain alcohol and porcine by-products and their derivatives. It should be manufactured, stored, packaged, and distributed according to the Islamic teachings. The halal beauty products are also recognised as clean, safe, and of high quality.

On the other hand, Dr Baker Alserhan (2015) stated that the type of alcohol used in cosmetic products is ethyl alcohol. It is used in many cosmetic agents both for men's (such as aftershave lotion) and women's (in perfumes) products. Ethyl alcohol is absorbed through the skin and flesh into the blood vessels and finally mixes with the blood and circulates throughout the body. Therefore, all cosmetic products containing ethyl alcohol are prohibited and haram. In 
addition, according to Islam (2013), cosmetic products are considered halal when all ingredients comply with halal and Syariah requirements as the product must be produce without haram ingredients such as alcohol and pigs are prohibited to be used.

\section{Analysis on Skin Toner Products}

In medieval times, the most important chemical discovery was the alcohol and mineral acids through the distillation process developed and controlled by the Arabs. Distillation was one of the most important processes in Islamic chemical technology and was employed for both medicinal preparations and a variety of other technological and industrial uses, including the preparation of acids, the distillation of perfume, rosewater, and essential oils (Hajar, 2000). This study also utilized a high-tech systematic tool, namely GC-MS. Gas chromatography-mass spectrometry (GC-MS) is used to identify alcohol substance in the cosmetic products and its status of halalness. Our research involved empirical evidences instead of theories. We must have the ability to analyse the sample by using the technology to obtain the data accurately. This is in line with the concept of halalan toyyiban. According to Elistina et al. (2010) halal for the products needs to look at the principles of halalan toyyiban including cosmetic and personal care.

\section{Gas Chromatography-mass Spectrometry (GC-MS)}

GC-MS was used to identify and compare the alcoholic compound in cosmetic products recorded through the spectrum mass in this study with the standard spectrum mass from the National Institute of Standards and Technology (NIST). The cosmetic products in this study were skin toners from different brands available in Malaysia. Meanwhile, the alcohol standards used in this GC-MS were pure ethanol and pure acetonitrile (ACN). These standards were used as references in calculating the concentration of alcohol detected in the analysed samples. Chauhan et al. (2014) explained that GC-MS is a hyphenated analytical technique that combines the spectrum properties of gas-liquid chromatography with the detection feature of mass spectrometry detection to identify difference compounds.

Figure 1 shows the calibration curve of pure ethanol and acetonitrile (ACN) used as reference standards.

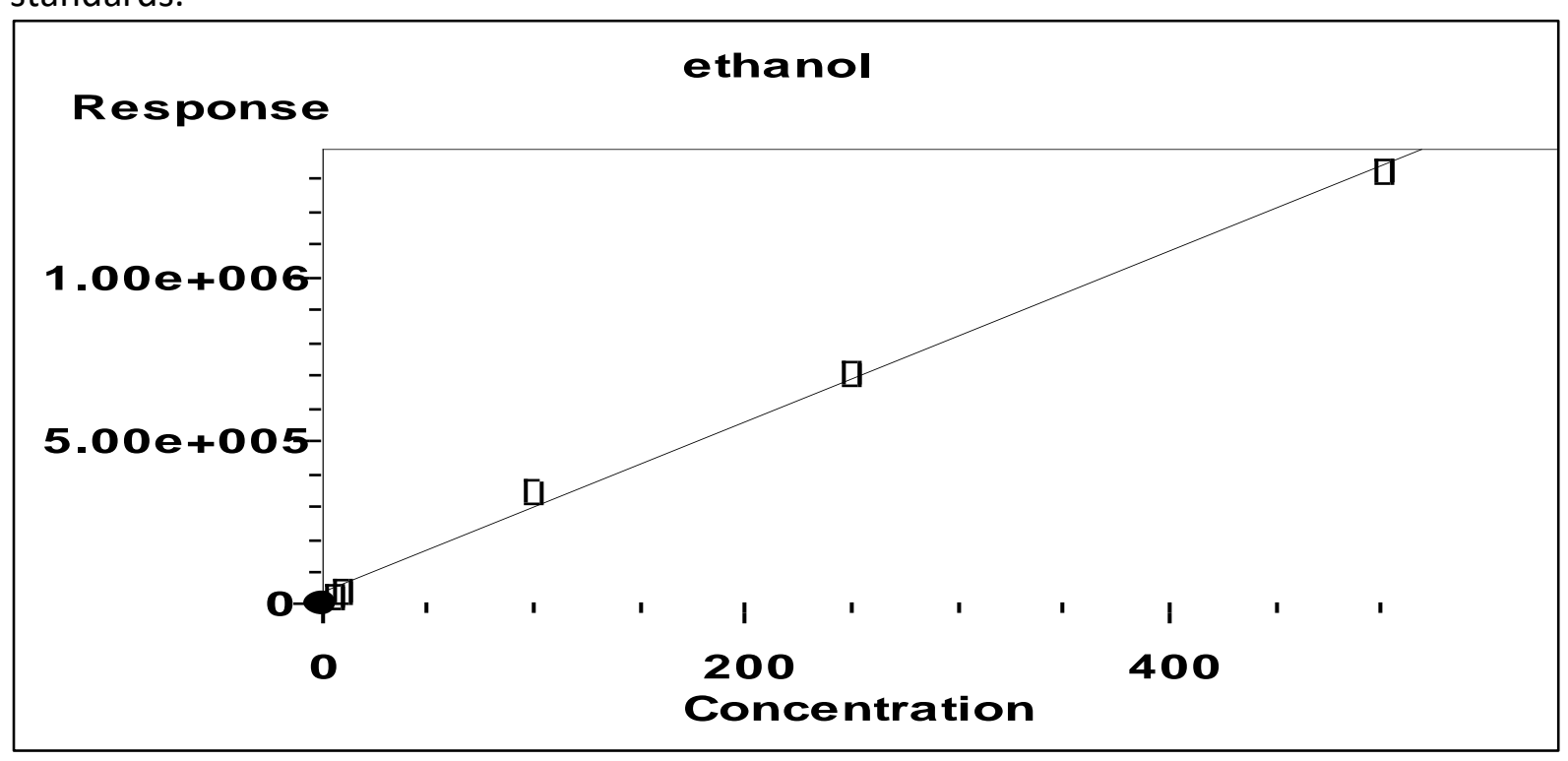

Figure 1: the calibration curve of pure ethanol and acetonitrile (ACN) 


\section{Chromatogram of Pure Ethanol and Pure Acetonitrile (ACN)}

Figure 2 shows the chromatogram of pure ethanol and pure ACN. The peak area of pure ethanol was $10.43 \%$ and pure acetonitrile (ACN) was $89.66 \%$. The retention time of ethanol and ACN were identified at minutes 2.874 and 3.646 , respectively.

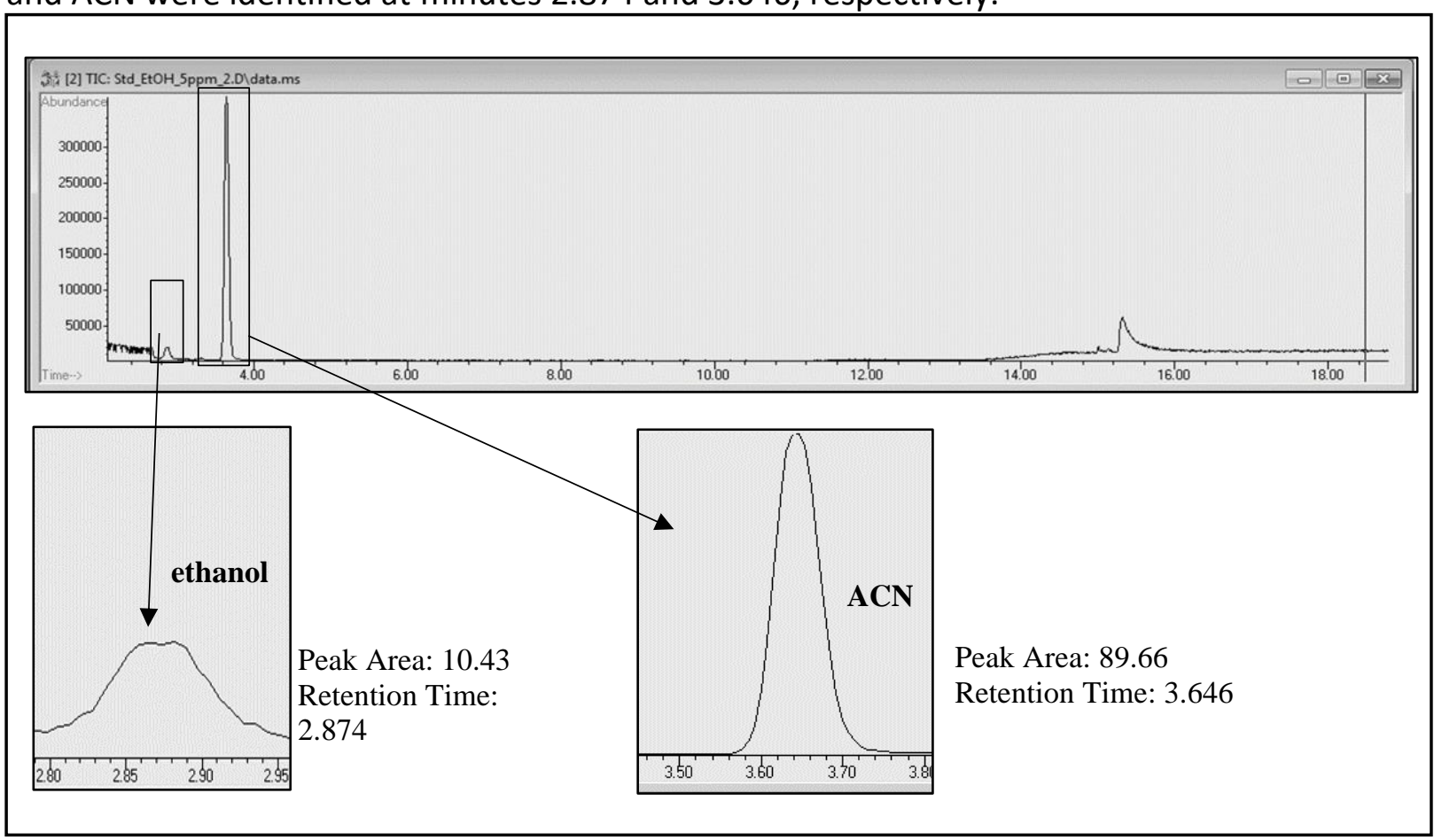

Figure 2: Peak area and retention time of pure ethanol and pure ACN

Figure 3 shows the fragmented ions of ethanol using mass-to-charge ratio $(\mathrm{m} / \mathrm{z})$. The three highest values of $\mathrm{m} / \mathrm{z}$ were 41.0, 40.0, and 39.0. Each molecule has a specific ion fragmentation that allows detection of ethanol in each sample.

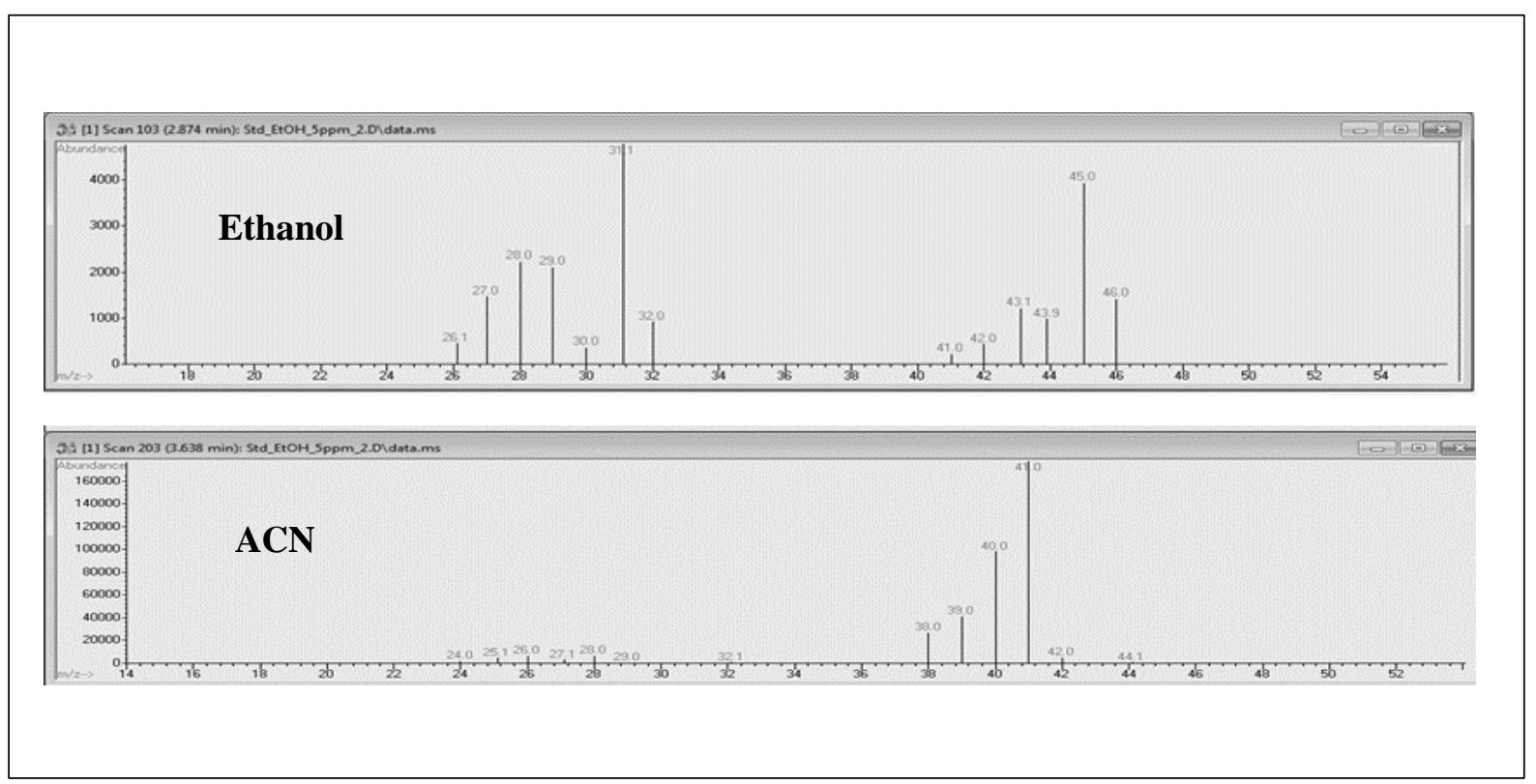

Figure 3: Fragmented ions of pure ethanol and pure ACN 
Figures 4, 5, 6, 7, and 8 show the chromatogram of samples of skin toners from different brands available in Malaysia. The retention time (Rt) was labelled for each peak in the chromatogram.

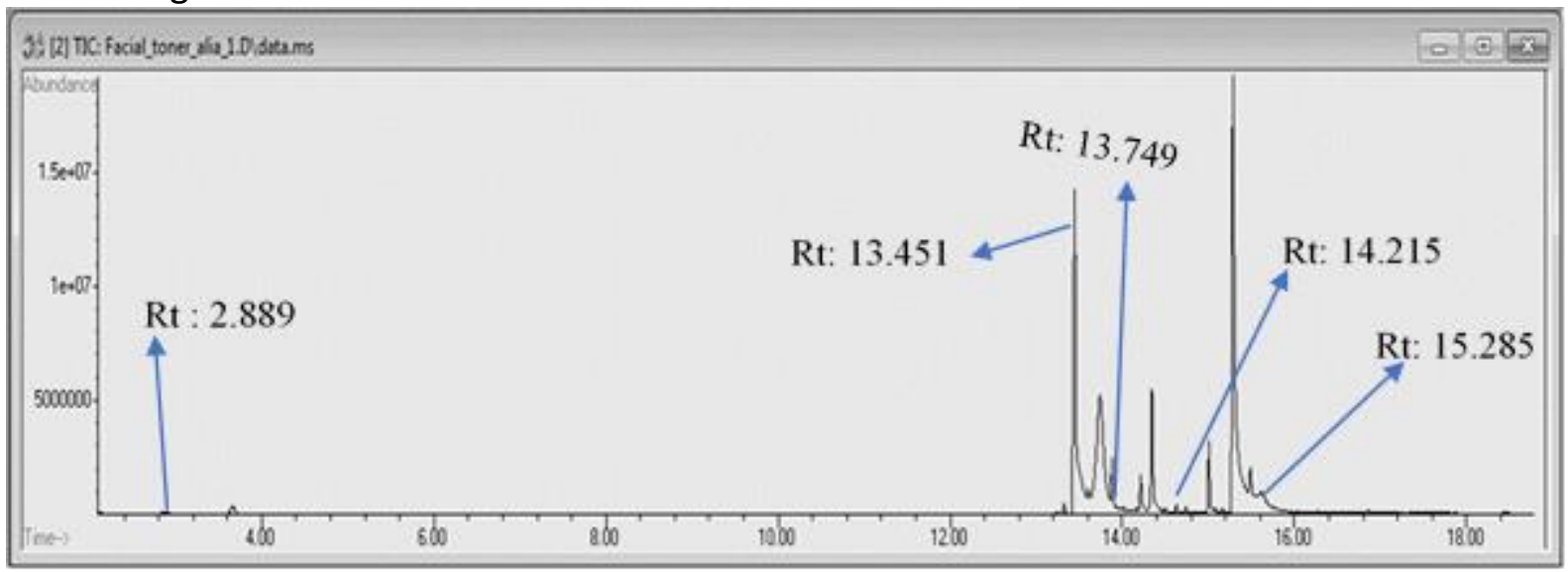

Figure 4: Chromatogram of Facial Toner Alia

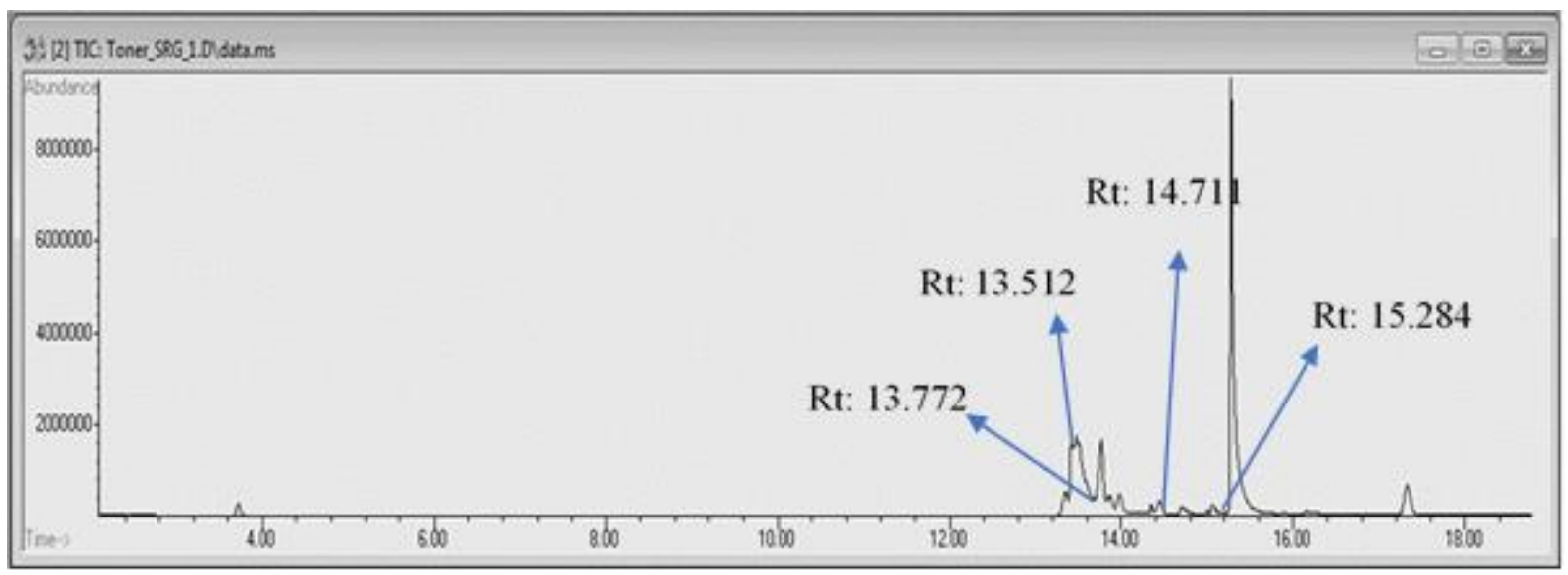

Figure 5: Chromatogram of Toner Safi Rania Gold ${ }^{\circledast}$

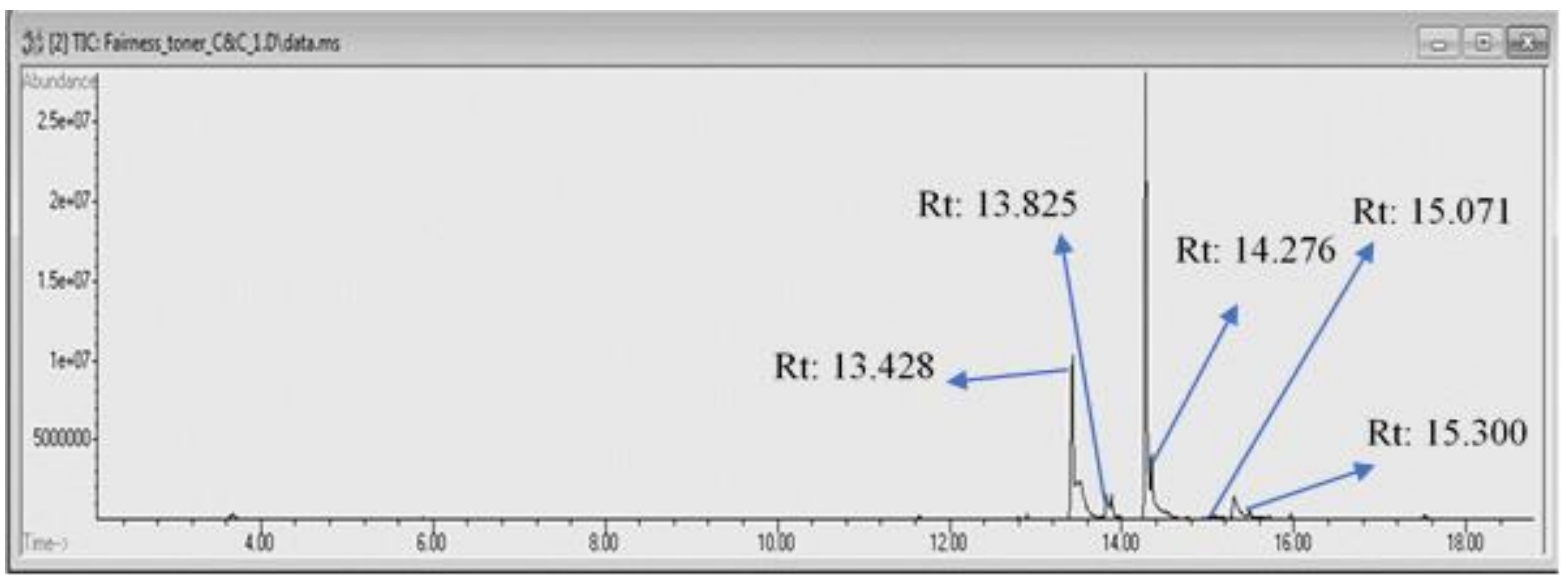

Figure 6: Chromatogram of Fairness Toner Clean \& Clear $^{\oplus}$ 


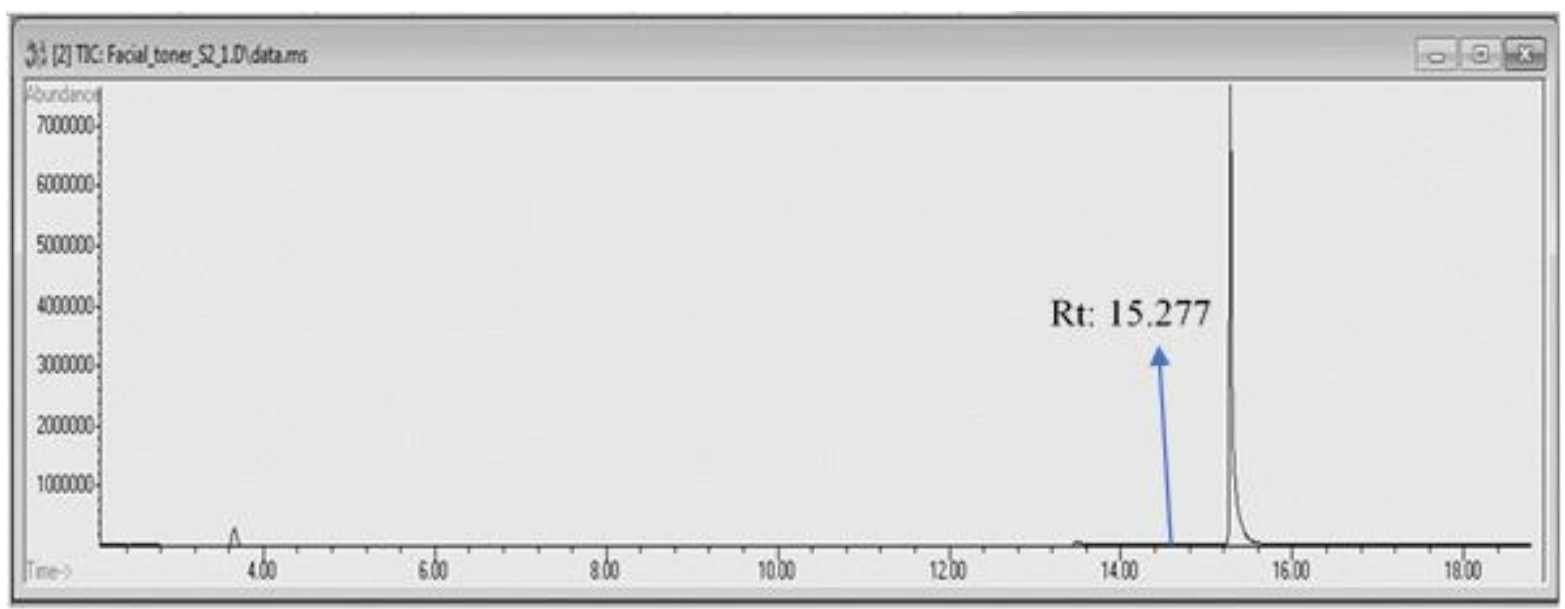

Figure 7: Chromatogram of Facial Toner Simple

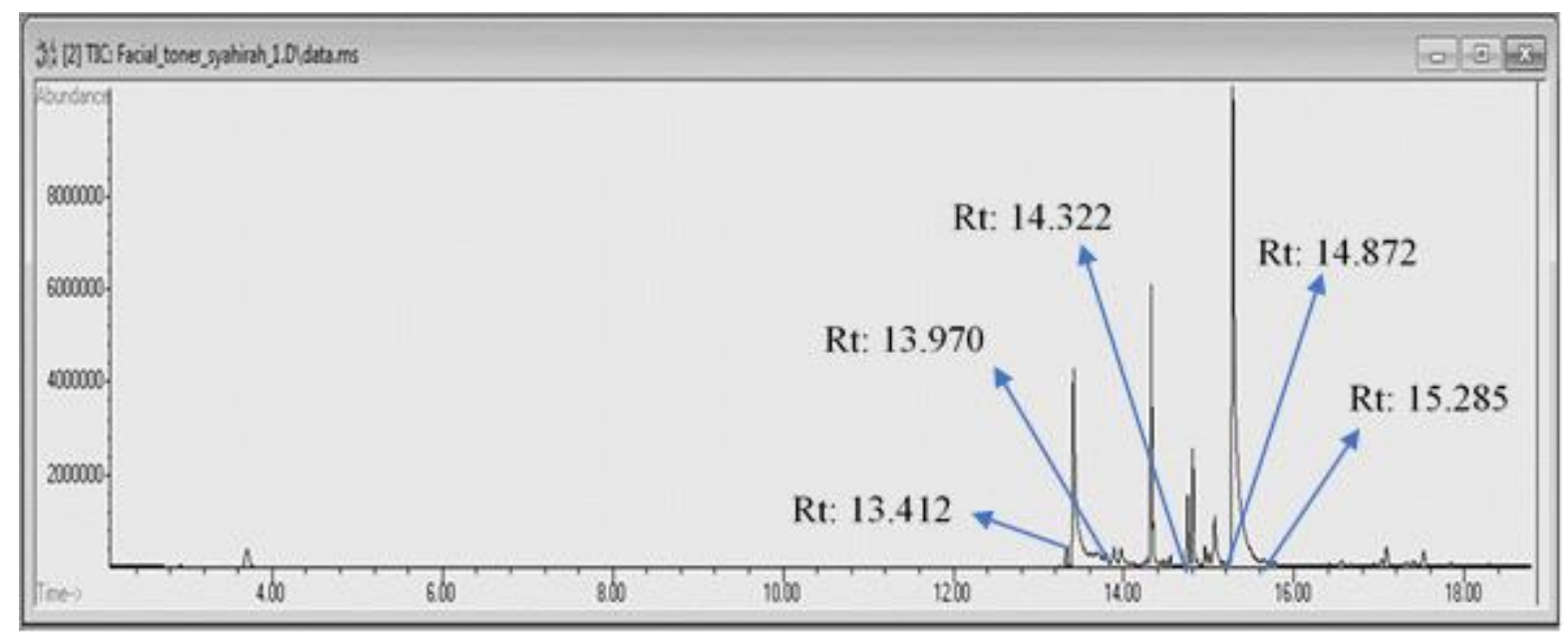

Figure 8: Chromatogram of Facial Toner Syahirah ${ }^{\oplus}$ 


\section{Result of Analysis Skin Toner Products}

Table 1 shows the types of alcohol found in the samples of skin toners.

Table 1: The types of alcohol in Skin Toners.

\begin{tabular}{|c|c|c|c|c|c|}
\hline No. & $\begin{array}{l}\text { Types of } \\
\text { Alcohol }\end{array}$ & $\begin{array}{l}\text { Retention } \\
\text { Time }\end{array}$ & $\begin{array}{l}\text { Mass-to-charge } \\
\text { ratio }(\mathrm{m} / \mathrm{z})\end{array}$ & Peak Area & $\begin{array}{l}\text { Quality } \\
\text { (\%) }\end{array}$ \\
\hline \multicolumn{6}{|c|}{ Sample of Facial Toner Alia ${ }^{\circledR}$} \\
\hline 1 & 1,3-Butanediol & 13.451 & $43.1,45.1,44.1$ & $23.04 \pm 1.44$ & 90 \\
\hline 2 & $\begin{array}{l}\text { 2-Phenoxy } \\
\text { ethanol }\end{array}$ & 15.285 & $94.1,138.1,77.1$ & $35.41 \pm 5.35$ & 91 \\
\hline 3 & 1,2-Pentanediol & 13.749 & $55.1,73.1,43.1$ & $15.29 \pm 6.59$ & 86 \\
\hline 4 & 2-Octanol & 14.215 & $59.1,55.1,43.1$ & $2.36 \pm 0.40$ & 72 \\
\hline 5 & Ethanol & 2.889 & $31.1,45.0,29.1$ & $0.45 \pm 0.16$ & 72 \\
\hline \multicolumn{6}{|c|}{ Sample of Toner Safi Rania Gold ${ }^{\circledR}$} \\
\hline 1 & 1,3-Butanediol & 13.420 & $43.1,45.1,57.1$ & $14.41 \pm 4.69$ & 90 \\
\hline 2 & $\begin{array}{l}\text { 2-Phenoxy } \\
\text { ethanol }\end{array}$ & 15.284 & $94.1,138.1,77.1$ & $46.96 \pm 4.53$ & 95 \\
\hline 3 & $\begin{array}{l}\text { Phenyl ethyl } \\
\text { Alcohol }\end{array}$ & 14.711 & $91.1,92.1,122.1$ & $1.49 \pm 0.31$ & 93 \\
\hline 4 & 1,2-Pentanediol & 13.772 & $43.1,45.1,55.1$ & $27.58 \pm 4.64$ & 90 \\
\hline \multicolumn{6}{|c|}{ Sample of Fairness Toner Clean \& Clear } \\
\hline 1 & 1,3-Butanediol & 13.428 & $43.1,45.1,72.1$ & $16.01 \pm 3.82$ & 90 \\
\hline 2 & $\begin{array}{l}\text { 2-Phenoxy } \\
\text { ethanol }\end{array}$ & 15.300 & $94.1,138.1,77.1$ & $2.43 \pm 2.96$ & 95 \\
\hline 3 & 1,2-Pentanediol & 13.825 & $55.1,73.1,43.1$ & $12.86 \pm 8.55$ & 83 \\
\hline 4 & Benzyl Alcohol & 14.276 & $79.1,108.1,77.1$ & $33.95 \pm 7.12$ & 97 \\
\hline 5 & Citronellol & 15.071 & $105.0,207.0,77.0$ & $0.73 \pm 0.06$ & 97 \\
\hline \multicolumn{6}{|c|}{ Sample of Facial Toner Simple ${ }^{\circledast}$} \\
\hline 1 & $\begin{array}{l}\text { 2-Phenoxy } \\
\text { ethanol }\end{array}$ & 15.277 & $94.1,77.1,138.1$ & $92.75 \pm 0.72$ & 91 \\
\hline \multicolumn{6}{|c|}{ Sample of Facial Toner Syahirah ${ }^{\oplus}$} \\
\hline 1 & 1,3-Butanediol & 13.412 & $83.0,55.0,43.0$ & $11.3 \pm 4.24$ & 90 \\
\hline 2 & $\begin{array}{l}\text { 2-Phenoxy } \\
\text { ethanol }\end{array}$ & 15.285 & $94.1,95.1,77.1$ & $39.8 \pm 3.28$ & 95 \\
\hline 3 & 2-Propanol & 13.970 & $43.0,45.1,55.1$ & $2.35 \pm 0.21$ & 83 \\
\hline 4 & 3-Octanol & 14.322 & $43.1,45.1,207.1$ & $9.5 \pm 1.02$ & 86 \\
\hline 5 & $\begin{array}{l}\text { Benzene } \\
\text { methanol }\end{array}$ & 14.827 & $\begin{array}{l}104.1, \quad 122.1 \\
105.1\end{array}$ & $0.30 \pm 0.06$ & 92 \\
\hline
\end{tabular}

Ten compounds (1,3-butanediol, 2-phenoxy ethanol, 1,2-pentanediol, octanol, ethanol, phenyl ethyl alcohol, benzyl alcohol, propanol, benzene methanol, and citronellol) were detected in the samples of skin toners using GC-MS as shown in Table 1.

This study has also been conducted by the lab researcher namely Miss Syariena. She has explained that all of these alcohols act as cleansing agents and solvents suitable for use on the skin. It has also confirmed that the alcohol is the synthetic alcohol through GC-MS. Table 1 in 4.0 shows the types of toners where alcohol is detected. The schedule also indicates the 
retention time, mass-to-charge ratio, peak area, and each alcohol molecule of each alcohol molecule based on the database obtained from the NIST library. As mentioned above, the value criteria and the selection of alcohol compounds are based on quality with the value of $60 \%$ and above. Therefore, in this study, the NIST library has accumulated data on mass spectra, chemical structures, and related information, which all show that the quality reaches $60 \%$ and above. The data results show that the mass percentage varies from $72 \%$ to 97 , but most of them are above $80 \%$.

The data of science analysis shows that the type of alcohol used in the samples is allowed in Islam because they are used externally and not for drinking purpose. According to Ministry of Health Malaysia (2005), synthetic alcohol is a substance produced through a chemical reaction, or a substance extracted from natural sources, which has been chemically modified. In addition, synthetic or man-made alcohol has very harmful properties because it is toxic when consumed in its natural form, but is purely for external use. This kind of alcohol is permissible and coincides with Malaysia Fatwa of the Muzakarah of the Fatwa Committee of the National Council for Islamic Religious Affairs on 11-12 April 1984 by JAKIM where the discussion on the issue of alcohol use in perfumes, medicines, and other sectors is as solvent and clean, if the alcohol is not derived from Khamr or liquor process which means that not all alcohol has Khamr. The Fatwa also mentioned that the permissible also including soft drinks that are not made into the Khamr or intoxicating substances, Tapai (a local fermented food) is halal to eat which the alcohol are produced as by-products of the process of making food and alcohol in medicine and fragrance. From the Fatwa that it should be understood that the alcohol substances used in the cosmetic products are permissible due to their purpose as cleansing agents and solvents.

The second evidence is the Islamic physicians and scholars in the 8th Nadwah Figh of Islamic Medicine which conclude that the alcohol is not najs in terms in Syariah and the use of alcohol in skin cleanser, creams, medicines, and other non-drinking products are permissible from the Islamic medical point of view (Hehsan, 2015). Both evidences are underlying of the method of figh as term as "the origin of any act is permissible". In fact, a very important understanding of alcohol is permissible in Islam if the alcohol is not produced through the process of making liquor since the alcohol obtained from the process of making liquor is forbidden in Islam.

The halalness has also been strengthened by the safety factor where the type of alcohol used in the sample indicates that it is for external use only, not for drinking. The compounds obtained in the research show that this liquid is suitable and safe for use on the skin. In other words, the results of this study also found that none of the ten compounds produced can cause side effects to the health of consumers such as can damage the skin and harmful such as alcohol alkyne and 4-tert-butylphenol (NPRA, 2020). According to Florence Barrett-Hill (2020), skin toner is also containing simple alcohol such as ethyl alcohol, isopropyl alcohol and denatured alcohol are derived from the fermentation of sugars, starches and other carbohydrates, which act as a solvent, they are us as thickeners or texturizers as well as other ingredients.

Synthetic alcohol also fulfills the meaning of Toyyiban because its function is to protect the skin. Alcohol-based toners for use in various skin types have the purpose of rehydrating the skin, balancing skin $\mathrm{pH}$, tightening skin pores, relieving irritation, and antisepsis. Pandey and Wasule (2017) states, the sugar in alcohol is used to make skin care products such as toners. This study emphasises the use and applicability of sugar in alcohol as a humectant. The results of the study show that the product is stable and the sugar in alcohol such as xylitol that acts 
as a moisturizer is suitable for use in skin care products. In addition, the study of Song et al. (2018) explained that several types of alcohol are used in cosmetics, including 2,3-butanediol. Butylene glycol can treat and moisturize the skin and reduce the viscosity of the product. In addition, butanediol can also dry out and re-stabilize formulations in cosmetics

However, there is fatwa of permissible of alcohol in cosmetics product but the Muslim researchers must continue in conducting the research of cosmetic product to confirm the halalness of them. This spirit has been mentioned by Kunthira et al. (2018). She expressed that to assure the Muslim consumers the Halalness of the cosmetic products, the ingredients or materials used in the production processes must be free from any doubtful (Syubhah) or prohibited (Haram) substances. Besides that, according to Elistina et al. (2010), halal elements of the products need to comply with the principles of halalan toyyiban including cosmetic and personal care.

\section{Conclusion}

The study has concluded that not all alcohol is najs or unclean in Islam. The prohibition of alcohol is only when the alcohol is derived from Khamr or liquor process which cause intoxication to us. This study has identified that the alcohol in the skin toner products is considered not unclean or najs due to their type of synthetic alcohol. The alcohol is used as a cleaning agent, solvent, and to provide durability for a certain period of time and good quality in cosmetic products. From an Islamic point of view, the use of alcohol as an ingredient in cosmetic products is highly dependent on its source and level of safety. Islam emphasizes the purity of a product both tangibly and intangibly for the halal status of a product. Therefore, the selection of ingredients should be guided by the Quran and the Sunnah. Meanwhile, scientific analysis indicates that the alcohol found in skin toner is not harmful to Muslim consumers because it is an organic compound and safe to use for our skin eternally only. This proves that the alcohol found in toners is safe according to literature reviews. In conclusion, the use of alcohol in skin toner products is considered halal for use because it is harmless and safe to use.

\section{References}

Al-Qaradawi, Y. (2016). Halal dan haram dalam Islam (M. H. Daud, Trans.). PTS Publishing House. (Original work published 1960).

Azmi, R. S. (2017). The Concept of Halal and Halal Food Certification Process in Malaysia: Issues and Concerns. Malaysian Journal of Consumer and Family Economics, 38-50.

Briliana, V., \& Mursito, N. (2017). Exploring antecedents and consequences of Indonesian Muslim youths' attitude towards halal cosmetic products: A case study in Jakarta. Asia Pacific Management Review, 22(4), 176-184. https://doi.org/10.1016/j.apmrv.2017.07.012

Chauhan, A., Goyal, M. K., \& Chauhan, P. (2014). GC-MS technique and its analytical applications in science and technology. Journal of Analytical \& Bioanalytical Techniques, 5(6). https://doi.org/10.4172/2155-9872.1000222

Alserhan, B. R. D. (2015). 6th Global Islamic Marketing Conference. Elite MAF Events \& Exhibitions, 1-29.

Elasrag, H. (2016). Halal industry: Key challenges and opportunities. SSRN Electronic Journal. https://doi.org/10.2139/ssrn.2735417. 
Elistina Abu Bakar, Nashaqilla Norlee Rosslee, Afida Mastura Muhammad Ariff, M. O., \& P. H. (2010). Consumers' Trust and Values Towards Halal Cosmetics and. Malaysian Journal of Consumer and Family Economics, 21-35.

Florence Barrett-Hill (2020). Alcohols in cosmetic formulations https://www.virtualbeauty.co.nz/alcohols-in-cosmetic-formulations/.

Hajar, R. (2000). Alcohol: friend or foe? A historical perspective. Heart Views, 1(9), 341-344.

Hashim, P., \& Hashim, M. D. (2013). A review of cosmetic and personal care products: Halal perspective and detection of ingredient. Pertanika Journal of Science and Technology, 21(2), 281-292.

Hehsan, M. R. (2015). Q \& A Fiqh Perubatan. Selangor: PTS Publications \& Distributions Sdn. Bhd.

Islam, T. (2013). International Journal of Management Research and Review, vol. 3, issue 12, pp. 3938-3948.

Kaur, K., Osman, S., \& Mustapha, S. M. (2014). Predicting working women purchasing behaviour of Malaysian Halal cosmetic products by using Theory of Planned Behaviour. International Academic Research Journal of Business and Management, 3(1), 1-7.

Teng, P. K., \& Jusoh, W. J. (2013). Investigating students awareness and usage intention towards halal labelled cosmetics and personal care products in Malaysia. International Conference of Business and Economic Research (4th ICBER 2103), 367-376.

Mahaiyadin, M. H., \& Osman, M. R. (2017). The effect of istihalah application in the products contain unlawful (muharramat) derivatives. Journal of Fatwa Management and Research, 10(1), 101-119. https://doi.org/10.33102/jfatwa.vol10no1.32

Mohezar, S., Zailani, S., \& Zainuddin, Z. (2016). Halal cosmetics adoption among young Muslim consumers in Malaysia: Religiosity concern. Global Journal Al-Thaqafah, 6(1), 47-59. https://doi.org/10.7187/GJAT10220160601

Mulaina, D. (2014). Analysis of Alcohol Levels in Circulating Syrup Cough Medicine in Pemalang City,1-13.[Undergraduate (S1) thesis, UIN Walisongo]. Walisongo Institutional Repository. http://eprints.walisongo.ac.id/id/eprint/4178

Mufti of Federal Territory. (2017). Irsyad Al-fatwa series 185: Alcohol swab and perfumes containing alcohol. Official Website of Mufti of Federal Territory. https://muftiwp.gov.my/en/artikel/irsyad-fatwa/irsyad-fatwa-umum-cat/953-irsyadal-fatwa-series-185-alcohol-swab-and-perfumes-containing-alcohol

Nor, S., Ahmad, B., Yunus, S., \& Rose, R. (n.d.). Hirao School of Management Review.

NPRA. (2020). List of Substances Which Must Not from Part of the Composition of Cosmetic Products, Annex II. National Pharmaceutical Regulatory Agency, Ministry Of Health Malaysia.

Pandey, D., \& Wasule, D. (2017). Evaluation of sugar alcohol: Humectant in skin care cosmetic. European Journal of Pharmaceutical and Medical Research, 4(2), 715-718.

Song, C. W., Rathnasingh, C., Park, J. M., Lee, J., \& Song, H. (2018). Isolation and evaluation of Bacillus strains for industrial production of 2,3-butanediol. Journal of Microbiology and Biotechnology, 28(3), 409-417.

Swidi, A., Cheng, W., Hassan, M. G., Al-Hosam, A., \& Mohd Kassim, A. W. (2010). The mainstream cosmetics industry in malaysia and the emergence, growth, and prospects of halal cosmetics. The Third International Conference on International Studies (ICIS 2010), 1-20. http://repo.uum.edu.my/id/eprint/2466 
INTERNATIONAL JOURNAL OF ACADEMIC RESEARCH IN BUSINESS AND SOCIAL SCIENCES

Vol. 11, No. 12, 2021, E-ISSN: 2222-6990 @ 2021 HRMARS

Yarkhan, N. (2009). Halal Consumer Magazine - A Publication of the Islamic Food and Nutrition Council America. Islamic Food and Nutrition Council of America (IFANCA),2829. 